\title{
FIGURING OUT ROMAN SLAVERY
}

\section{By E. BADIAN}

K. HOPKINS, CONQUERORS AND SLAVES. (Sociological studies in Roman history I). Cambridge, 1978. Pp. xvii + 268, I map, 4 pls., 3 figs., 11 tables.

The preface describes this as ' a book about the Roman empire'. In fact it is a series of essays, the three most important of which (pp. I-17I) are in some way concerned with slavery under the Roman Republic: two in Rome itself and one at Hellenistic-Roman Delphi. To these are added a slightly revised reprint of a useful article (of 1963 ) on court eunuchs under the Empire, and a wellinformed popular essay on emperor worship, illustrated by four pages of plates. (One suspects they were added to make what someone thought a book of proper length.) The first of these is an orthodox article, in no way sociological, while the second is not a work of original scholarship. Yet the price is no doubt doubled by the inclusion of these two pieces and the unnecessary illustrations that go with the second. The practice of increasing the bulk and cost of scholarly books by unjustifiable additions has become almost a hallmark of British academic publishing. It must be strongly condemned, for the sake of the shrinking circle of ' consumers ' thus deliberately priced out of the market. I shall confine my comments to the first three studies, connected in method and content and forming what one might call the real book.

We must start by quoting the author's preface on his method and its justification. He claims that we, as ' conventional' historians, 'finish up by foisting simplifying fictions on the complexities of a past which is largely lost' and that 'one of the persistent problems ... is how to choose between competing fictions ' ( $p$. x). If, for ' foisting simplifying fictions on', we read ' constructing simplifying models of ', this (with consequential changes) is by no means new: except for the emotive language, it would be admitted as a truism of method. In more restrained mood (96), expressing what seems to be his considered opinion, $H$. admits that ' all approaches ... are necessarily selective and partial ', including his own. This does not imply that all are valid, even within self-imposed limits; but any that claim universality tend to approach inanity. He argues that, in the choice between the 'fictions' (i.e. historical models), sociological methods can be helpful, as 'attempts to reveal how Romans thought and to measure links between factors'. If for ' measure ' we substitute ' trace ', these would be agreed to be among the chief aims of all historians. In fact, H.'s method, far from helping us choose between models, merely adds another set of models to the choice we have. It is by ' measuring ' (in the strict sense) that it makes its contribution. Thus, while suitable for the second of H.'s aims, it is irrelevant to the first. H. almost admits this. 'The ancient sources', he says, 'tell us only what an ancient author thought was happening and how he felt about it, or how he thought that others felt about it.' 'This (oddly omitting most non-literary sources) is given as a reason for not normally citing ancient sources. Now, one who genuinely aims to help us ' reveal how Romans thought ' must surely attend precisely to 'what an ancient author thought was happening and how he felt about it, or how he thought that others felt about it ', at least to start with. H. would do better to abandon this claim and to limit himself to measuring links between factors.

Needless to say, he does use ancient sources. There are references to them on every page for long stretches, sometimes with full verbatim quotations of astonishing length. As every historian knows, the facts are not discrete objects to be picked up and linked: they are precisely what is gathered from ancient authors and documents. Analysis can begin only after that first step of selection, i.e. simplification. The price paid for ignoring this literally basic importance of the ancient evidence is often clear : the argument can be derived from that very evidence, only at second hand, and much to its disadvantage. The lack of what one might call the historian's basic humility before his sources (no matter how he finally feels compelled to deal with them) leads to uncertainty in evaluation, to misinterpretation, indeed to sheer invention, of the evidence. Thus $(6 \circ, n .85)$ it is claimed that a wellknown passage in Cato's Rhodian Oration $\left(O R F^{3}{ }^{167}\right)$ shows that ' in 167 B.C. . . . men held more than 500 iugera of state land with impunity'. As anyone actually reading the passage will see, it shows the very opposite : that compliance with the law (even if some in fact were breaking it, as some always do) was taken for granted by Cato and his audience. The error, no doubt due to taking the interpretation at second hand, vitiates part of H.'s interpretation of the development of large estates. Worse still : tendentious mistranslation for rhetorical effect, or invention (no doubt again at second hand) of non-existent texts. For the former, see (I I 5 ) a distortion of a legal rule in the jurist Julian into support for a trite moral judgment; for the latter, an implausible passage (99) assigned, without a line number, to Plautus' Amphitruo : patient search failed to discover anything resembling it. Again, two full pages of Plutarch's Tiberius Gracchus (58-9, 61-2) are copied out, presumably as an essentially valid account 
of the events of $I_{33}$ B.c. and analysis of their background (despite a disarming admission, $63, n .87$ ). Certainly, all these practices could be paralleled in 'conventional' historians. But they would in principle reject them, and put any of their colleagues discovered using such methods in the stocks.

On the other hand, H. sometimes chooses to disbelieve ancient evidence on a priori grounds that will not stand up to scrutiny, and he censures ' conventional' historians for not doing so. Thus he charges E. T. Salmon with ' uncritically' accepting the ancient figures on the size of third- and second-century colonies, which he himself thinks impossibly large: his favourite source, the U.N. Model Life Tables, reveals that 4,000 adult male settlers would involve an initial population of 13,000 and 6,000 males one of 20,000 ; which is clearly impossible. I am not concerned with the accuracy of ancient figures, but with method in evaluating them. What is patently erroneous is H.'s ' uncritical ' postulate that the initial population of a new colony would exactly mirror the composition of the population at large. (And this quite apart from any doubts one might have about the U.N. Tables as such.) He does not seem to be aware that he is making this large assumption; nor has he looked, e.g., at the demography of agricultural settlements on the American frontier in the Igth century. J. E. Eblen, Demography II (1965), 399-413, allows (with all due reservations regarding his use of his evidence) glimpses of some interesting facts, based by a complex computation on the censuses of $1840,185^{\circ}$ and 1860 . The U.S. as a whole had $8 \%$ fewer males and $10 \%$ more females than a construct of an agricultural frontier county. In the upper age range, the difference rises from $6 \% \mathrm{~m}$ and $35 \% \mathrm{f}$ at ages $40-49$ to $44 \% \mathrm{~m}$ and $130 \% \mathrm{f}$ at ages $60-69$. Between ages 20 and 40 , there are (in two censuses) 26 and $22 \%$ fewer males in the U.S. than in the 'frontier county'. Even though the situations are (of course) not fully comparable, such figures confirm one's natural suspicion that H.'s uncritical postulate in using the Model Life Tables vitiates his argument. Recognition of a colony's highly selective composition - as of the attested fact that colonies admitted at least some non-citizens to membership-shows that Salmon was far less uncritical than his critic.

Indeed, clarity of methodology is not one of his strengths. There might be no harm in that. The sociologist is better employed doing sociology than writing about its philosophy, just as the historian is better employed writing history than philosophy of history : excellence in the former and in the latter do not necessarily go together. But $H_{\text {., }}$ as though under a strange compulsion, keeps returning to methodology, and this makes it harder for the reader to understand and assess what it is that he is actually doing. In particular, he seizes chances of lashing out at 'conventional ' historians. Thus he complains $\left(6_{5}\right)$ that our books are 'organised primarily by time, not by topic or problem'. No doubt general textbooks and similar works are: it is often the only way. But, as a glance at any library shelf would show, books and articles presenting scholarly research by 'conventional ' ancient historians do study (in the classic formulation) ' problems, not periods'.

Again, he charges that 'the evidence is often so thin that motives ... can be deduced only from behaviour-a speculative process to say the least '. That in ancient history the evidence is usually thin and interpretation speculative is true not least of his own interpretations, as he often properly stresses (e.g., at random, 68 top ; 98). As for the deduction of motives, that is always a speculative business; but how else could they be deduced, in ancient history or in our own life, but from behaviour, verbal and non-verbal? They are thus deduced, of course, by sociologists-except that sociologists tend to attach disproportionate importance to highly stylized forms of behaviour (e.g. answering questionnaires), rather than the natural forms that interest the historian.

Lack of clarity in methodology is perhaps less serious than it is in actual exposition; for that can make exposition unintelligible. Thus, we are invited to assume (15) that 'four fifths of the Italian and provincial labour force were primarily engaged in producing food '-perhaps a reasonable guess. [My italics, here and in the rest of this paragraph.] We are next given a further assumption that the 'average consumption by townsmen ... was near that of peasants'-less obvious, at least in the late Republic, since the conspicuous consumption of the upper class, extending to its households, must have raised that average. However: it follows that 'it took four food-producing families to feed a fifth'. The model is deceptively simple and clear: the population is assumed to be identical with its labour force and is divided into neat 'families', four fifths of which feed the whole. That model may approach the state of affairs in (say) fourth-century Italy, but it only has to be made explicit to be recognized as manifestly impossible for the first century. Large sections of the populationagricultural slaves; the urban unemployed and quasi-unemployed; town-dwellers who worked in the fields as seasonal labourers, in town the rest of the time; even soldiers (a significant part of the population)-for various reasons do not fit into it. The model is never openly presented; but as soon as we make it explicit, it is shattered by the refractory categories. Next, H. concludes from all this that 'agricultural productivity was low since it took four ... families to feed a fifth '; and next, that 'on average, Roman peasants consumed four-fifths of their own produce and supported nonpeasants with the remaining fifth '. Are we thinking in terms of families unanimously working the land or not doing so; or of individuals, some or all members of families? Where, in this model, do we account for the non-working members of a peasant's family? Or for those who do not work on the 
land? Finally, H. contrasts these 'facts' with the modern USA, where ' one farm worker produces enough food for over fifty people'. Here, of course, the farm worker's small children and his old mother are clearly among the people supported by him. Though part of an agricultural family, they are consumers of its labour. By now the ' conventional ' historian is utterly confused, not sure what the author is really talking about. Some of the diagrams, too, are no less confusing than these paragraphs (e.g. fig. I.I, p. 12) or simply redundant (e.g. 1.2, p. 17). The reader might well give up in frustration.

II

It would be a pity if he did so: he would miss some truly important results. Let us, however, first test H.'s claim that, even if the details of his attempts at quantification are not accepted, the result will often not be greatly affected : that claim is basic to the method and the results. The Roman army provides a test case. H. rightly stresses the military tradition that governed Roman life and, basing his figures on Brunt's, tries to quantify them; he arrives at a median (between 225 and 23 B.c.) of $13 \%$ of the adult male population on military service at any one time. He is wrong in taking the paper strength of the legion (as given by Livy) as its actual strength: as Polybius tells us (and we have no good reason to disbelieve him), that was 4,000 to 4,500, raised to 5,000 in emergencies. Similarly, in the post-Marian legion, we have no more reason to think that the paper figure of 6,200 was normally attained. $H$. has seen this for $9 \mathrm{I}-33$ B.c. But all other figures should probably be scaled down by about $20 \%$, and (for a fair assessment) the emergencies of the Hannibalic War and of the civil wars should be excluded. These corrections bring the median down to $11 \%$, and the mean is almost unchanged. H.'s claim of the significance and essential accuracy of his calculations is reassuringly borne out. By some simple calculations (34-5) he produces the truly 'staggering ' result that between a third and a half of the adult male population must have served between seven and ten years. We ought to add that, since before Marius only assidui were accepted for service, whereas proletarii must at all times have made up a significant (though unquantifiable) proportion of the population, the burden on assidui, during much of the history of the Roman Republic, is almost unimaginable. The 'conventional' historian never had any idea of this. It makes the need for the army reform vividly intelligible, and it provides a concrete background to the economic and social developments that $H$. proceeds to set out in the next half of this essay.

Yet one doubt remains, not considered by him. He stresses that the strain on manpower is unparalleled in known history (comparing, e.g., Frederick the Great and Napoleon) and that it was due to 'the competitive ambitions of a militaristic élite'. The characterization will not be denied. But are the comparisons truly relevant? We have no better ones to make, for, poor as the record is for Rome, it is the only one in antiquity that does at least provide a series of figures of a sort. To assess their significance, we should need to know, not about Napoleon, but (e.g.) what proportion of Aequi or of Samnites, before the Roman conquest, were at any one time doing military service. When we are told that Rome was engaged in war literally every year, it seems that she merely carried onmuch longer and on a much larger scale--the traditions of primitive Italy. For that matter, we do not know how many fifth-century Athenians, on average, were doing military service, and how long they had to serve.

The long survey of economic, administrative and social developments is, on the whole, uncontroversial textbook material. H. adopts a modified form of Toynbee's thesis, which, throughout the second century, sees a process of accumulation of land in the hands of large owners and a corresponding eviction of peasants, who migrate into cities (especially Rome), into colonies and perhaps overseas. (Following Brunt's demographic conjectures too closely, he seems to underestimate the amount of Italian emigration to the provinces, i.e. Italian fertility in the second century.) $\mathrm{He}$ explains army service as another form of emigration, in that it took men off the land; and he makes it clearer (to many of us for the first time) how small farms could survive the constant drain on manpower, by pointing out that in comparable economies underemployment is in fact normal: in a sense, the army took up the slack. (One is reminded of Hitler's solution for German unemployment.) It might be worth mentioning that, under the Empire, Columella $(R R$ II 12,9$)$ budgets 75 free days a year for labourers and teams-not an ungenerous allowance, in rural conditions. (In the city, then as now, the number was, of course, far larger.)

Throughout these long surveys, there is the redeeming flash of quantification to reward the reader's patience; as when we find $\left(55^{-6)}\right.$ that the 600 senators owned enough land to feed 800,000 people at subsistence level. And $\mathrm{H}$. is scrupulously honest in assessing the limits of legitimate calculation. Thus he supports Beloch's figure of $800,000-1,000,000$ for the population of Augustan Rome, 'but it is only a guess'; and his conscientious collection of the miscellaneous evidence by which it is supported should convince anyone that the numbers game is often not worth playing: in cases such as these, although it is eternally fascinating, it has nothing to do with scholarship. Similarly, 
he repeatedly (and usefully) stresses that we have no basis for estimating the total number of slaves in Italy at any time (one might add that this is true almost everywhere else, except perhaps for some periods in Egypt). What the historian has always suspected is now confirmed by the scrupulous demographer.

III

The second essay deals with ' The growth and practice of slavery in Roman times '. He first gives a definition (now widely accepted) of a 'slave society' and discusses the growth of the Roman one. Unlike Finley (and rightly, as most historians will think), he regards slavery in early Rome as relatively unimportant and discards the anachronistic fictions produced by historians in the late Republic. As we have seen, he does not try to guess numbers of slaves. He is always aware of the limitations of the evidence. Figures, as he remarks in an aside (105, n. I3), 'sometimes give a spurious precision to data of varying reliability'. It should be clear that, with all his massive quantification, he is always aware of the temptation and rarely succumbs. Indeed, he can be too conscientious, as when he refuses to use the 'formal modules' of farm sizes given in the agricultural writers as evidence for actual sizes : one might remind him of his own frequent insistence on 'orders of magnitude ', which is as useful here. If we find a farm of (say) 25 ha. in Cato, we may confidently deduce that he was not writing for a circle where farms of 250 ha. were the norm. He is thus unjust to $\mathrm{H}$. Dohr, whose demonstration (in Die italischen Gutshöfe ( 1965$)$ ) of the essential difference made by the size of a farm, and discussion of the treatises in the light of this, remains a valuable contribution.

One of H.'s most brilliant suggestions is that, if agricultural slavery was to make sense, there had to be a market for the produce; for one of the aims of introducing slave labour was to increase production. This simple point (obvious once thought of-which, as far as I know, it had never been) leads to interesting conclusions. The produce had to be sold in the cities, especially in Rome ; and it follows that we have exaggerated the difficulty of transporting it over long distances to Rome. After all (as he points out), much of it could be transported by water, just as it was from the provinces. Next, he shows that the distribution of wheat to the Roman plebs helped to provide the needed market for the products of capital-intensive agriculture (e.g. wine and oil) by giving people money to spend on them. The Roman landowners who opposed the wheat subsidy obviously failed to see this; just as they failed to see the fact that colonisation (which they consistently opposed, after the early second century) freed land for them to purchase without creating the potential for revolution. Nor are these points that were seen by our sources. Here, in the field of analysis, H.'s refusal to be tied down by the sources is fully justified. His unreasonable attack on the use of sources, which we noted earlier, must not be met with equally unreasonable imprisonment within their perspectives. Too many ' conventional' historians of antiquity, especially those trained in the German legal and philological tradition, have in the last two generations opposed attempts at such analyses with the damning verdict that 'it is not in the sources ', even though their predecessors (men like Meyer and Beloch) never questioned the use of principles and methods unknown in antiquity. It is perhaps worth noting that it was precisely the influence of sociological studies in Germany that again made them acceptable to a younger generation of German scholars. Just as the sources must provide our sole evidence, they must not provide our sole canons of interpretation.

Next, 'Why slaves and not citizens?' (ro8 ff.), especially on the land. Whether or not we accept H.'s figures for the cost of slaves, we can certainly never again think of them as cheap and plentiful except on rare occasions. So the problem of why to so large an extent they displaced free labour becomes even more puzzling. As $H$. points out, the very fact that peasants lost their land created a pool of cheap free labour. Why were slaves preferred? Especially as writers ancient and modern frequently comment on the advantages offered by free labour. I am not sure that $H$. finds a satisfactory answer. That there was no ' labour market' is true, but not very relevant. That free men refused to work for pay, as is often asserted, is false: they are amply attested, both as tenants and as seasonal workers. That employment of slaves on large estates created ' economies of scale' ought to be proved, not asserted as self-evident. It may be anachronistic. It is likely that they could be made to work longer hours than free men (though H.'s unwillingness to collect actual evidence is nowhere more unhelpful than here); but they worked less efficiently, as we are constantly told. And they had to be fed in idleness and illness, for they were (as H. has shown) a costly investment. The case is not made out. Nor is the plea of ' specialization' convincing. 'The skills of ox-drivers or vine-dressers (cited by H.) were undoubtedly soon acquired by any free farmer. Here the implied parallel of our industrial society has produced patent anachronism. It is not shown that Roman land-owners saw an appropriate 'profit' (in some sense of the term) in investing in slaves. The 'profit', moreover, would have to be an obvious one, for (as H. notes) their economic thinking was less advanced (even) than ours. And free tenants and labourers provided electoral support, after all; whereas $H$.'s suggestion that 'slave-ownership conferred status' is true only for domestic establishments : it can have no relevance to agricultural slavery. 
Perhaps some of H.'s points, implausible though they look, can be made acceptable by the collection of proper supporting evidence. In the meantime, I would make an obvious suggestion. Free men, unlike slaves, were liable to conscription. By relying on them, the rich landowner might take upon himself a multiple of the problems that beset small peasants. For the second century, when the movement towards farms relying on slaves for their resident labour force makes significant progress, that would not be widely believed today. For it implies a further hypothesis : that tenants, like owners, were registered in the census as assidui. This heretical suggestion can be supported. It is difficult to see how Ti. Gracchus' land law, which did not make those who received allotments owners iure quiritium, could have solved Rome's manpower problems (which, as all the sources assert, was at least one of his principal concerns), unless tenants of public land were liable to service. And I have already suggested $(A N R W$ I I $(1978), 673)$ that, if this applied to public land, it ought on the same terms to apply to private, since it is difficult to think of a legal basis for differentiating. The missing answer to the important question raised by $\mathrm{H}$. may be provided by this suggestion, which had previously been made in a totally different context. It is in the first century B.C., in fact, when conscription, though it did not cease (as Brunt has shown), was considerably alleviated and ceased, in normal times, to be a major concern-it is indeed then that we have rapidly increasing evidence for the use of free tenants. It is true that, as $\mathrm{H}$. shows, the Roman military achievement in the second century rested largely on a basis of agricultural slavery; but the details still need much thought and investigation before we can properly account for the process.

Finally, the question that any treatment of Roman slavery must face: 'Why did the Romans free so many slaves?' (I15). The actual numbers game may again be left to those who like to conjure up figures based on no evidence. (There is none that matters.) $H$., as usual, is scrupulous to avoid pseudo-quantification. But it is clear that the numbers were substantial. H. gives a good survey of slaves high and low, of treatment generous and brutal; though a knowledge of legal sources (both literary and epigraphic) would have greatly improved this part. But again he wilfully attacks "conventional' historians, who 'have usually described the emancipation of slaves from a humanitarian point of view' ( 117 ). Such obvious facts as the 'incentive' effect of possible emancipation, which he claims as an original discovery, and (after 122 B.C.) the advantage of getting a public subsidy in feeding a male slave freed near Rome-these motives are well known to the ancient sources (which, of course, $H$. is not greatly interested in consulting) and are commonplaces in any modern treatment. His unfamiliarity with legal sources leads him to regard the payment of the market replacement price out of the slave's peculium as universal, which it was not; and in any case, the payment of a price is no explanation of the practice of enfranchisement: it is, at best, part of the problem. For if the master had not allowed the accumulation of a peculium, he could in due course have collected the same amount (or, probably, more) for himself without freeing the slave. On this and related matters, $H$. would have been well advised to devote more careful attention to Susan Treggiari's Roman Freedmen during the Late Republic (1969), where the facts and the ancient evidence are collected and analysed (II-20).

H. sets out the profit derived from a freedman (again, Treggiari's remains the standard treatment) and recognizes motives of status and affection. But his final verdict (128) is harshly realistic: 'In the final analysis, the liberation of so many slaves was acceptable to masters only because it was profitable.' This generalization is not very profitable. As $H$. well recognizes in detail, but refuses to consider in his judgment, the "human' element must not be left out of account in such personal relationships. On the crudely realistic view, the unsolved problem is the known difference between slaves in agriculture or mining and domestic slaves as regards chances of emancipation. In theory their status was the same. But slaves whom one got to know (even fleetingly) as human beings were simply different from slaves who appeared as items in account-books. Their human identity could not be so conveniently ignored (though undoubtedly it might be by some). As has been pointed out in connection with Eichmann and others, the sadists who performed the beatings and executions in the concentration camps of Hitler's Europe were relatively unimportant in the 'final solution '. The real job was done by the bureaucrats who knew the victims only as entries in official files; and many of them, it seems, would have been incapable of beating, let alone killing, an actual human being. The facts we ourselves have witnessed no longer permit us to accept crude generalizations about pure profit motives. Perhaps 'conventional ' historians who, unlike sociologists, are interested in human beings chiefly as individuals, still have a legitimate function.

The third study is, in a way, the jewel of the collection. It deals with a limited problem : manumission of slaves at Delphi between $20 \mathrm{I}$ B.C. and A.D. 10O. It is a problem very amenable to statistical approaches, and there is no other evidence. It would be churlish to complain about details, but I must say that, in such cases (where the population on which the calculations are based is often very small) 
I should always like to see, somewhere in a note, the results of tests known to any elementary student of statistics, to show which of the figures are significant at what level. For as $\mathrm{H}$. recognizes, figures may 'give a spurious precision'. Still, he succeeds in showing the high and (in general) increasing cost of buying one's freedom at Delphi, and the increasing limitations on that freedom imposed with increasing frequency. There are also interesting conclusions about slave families and the way they were treated by owners. No one (I think) had ever attempted to extract such significant information from such ' raw' data. We cannot help wishing we could know how far the conclusions extend beyond this remote corner of the Greek peninsula. H. very properly practises the ars nesciendi that is an essential part of the equipment of any honest student of antiquity.

The verdict on the work as a whole must be mixed. The general passages can for long stretches be trivial and (owing to the author's attitude to the sources) second-hand. Even there, as we have seen, a brilliant flash often demonstrates that H.'s methods, properly used in addition to 'conventional' ones, can provide new insights into Roman economic and social history. Careful attention to clarity in methodological conception and in detailed execution might have further increased the benefit. The feuding against ' conventional ' historians is deplorable. It would be better for H.'s own work if he fully realized what they have to offer, and it unfortunately makes it less likely that they will appreciate what he offers. At least one ' conventional' historian learnt a great deal from his book; though at times it required a great deal of patience.

Harvard University 